\title{
Optimization of RAPD-PCR reaction system for genetic relationships analysis of 15 camellia cultivars
}

\author{
X. F. Wang ${ }^{1,2 \star}$, W. H. Zheng ${ }^{1}$, H. X. Zheng ${ }^{1}$, Q. Q. Xie ${ }^{1}$, H. Y. Zheng ${ }^{1}$, H. Tang ${ }^{1}$ and Y. L. Tao ${ }^{1}$ \\ ${ }^{1}$ Life and Environmental Science College, Wenzhou University, Wenzhou, Zhejiang province, People Republic of China, \\ 325027. \\ ${ }^{2}$ Life Science College, Zhejiang University, Hangzhou, Zhejiang province, People Republic of China, 310058.
}

Accepted 31 December, 2009

\begin{abstract}
With orthogonal analysis by $\mathrm{L}_{27}\left(3^{6}\right)$, the random amplified polymorphic DNA (RAPD)-PCR optimization reaction system for camellia were obtained. Results showed that the optimization system was $10 \times P C R$ Buffer $(2.5 \mu \mathrm{L}), 25 \mathrm{mM} \mathrm{MgCl} 2(2.5 \mu \mathrm{L}), 2.5 \mathrm{mM}$ dNTPs $(2.0 \mu \mathrm{L}), 20 \mu \mathrm{M}$ primer (1.0 $\mu \mathrm{L})$, Tag (1.5 U), temple DNA (40 ng or so) and added $\mathrm{ddH}_{2} \mathrm{O}$ to the total volume $25 \mathrm{uL}$; suitable annealing temperature was $36^{\circ} \mathrm{C}$. With the optimized system and fifteen $10 \mathrm{nt}$ random primers, we analyzed 15 camellia cultivars and observed 102 clear amplified loci, in which polymorphic loci were 79 while the percentage of polymorphic loci were $\mathbf{7 7 . 5 4 \%}$. Cluster analysis showed that the four groups were divided at the point 0.75 of similarity coefficient, indicating relatively high genetic diversity. We also found that the gene controlling petal color may play an important role in RAPD analysis. Moreover, genetic diversities based on RAPD analysis could be clearly reflected by morphological traits among 15 camellia cultivars. This study showed the RAPD optimization system was suitable and RAPD molecular marker was effective and useful tool for detection of genetic relationships among camellia cultivars.
\end{abstract}

Key words: Optimization, RAPD, Camellia cultivars, genetic relationships.

\section{INTRODUCTION}

Camellia features beautiful tree shape, various petal color, and graceful shape of flower. What is most important, it still blooms in winter during which few gardening plants could bloom. So camellia is regarded as an importantly ornamental horticultural plant. Moreover, it can afford raw material for tea beverage, edible oil and Chinese traditional herbal medicine (Ferrara et al., 2001; Chattopadhyay et al., 2004; Khan and Mukhtar, 2007; Gao et al., 2005; Tadahiro et al., 1985).

Genus Camellia belongs to Theaceae in Theales, grown natively in Southeast Asia. Presently, it has been introduced into many nonindigenous countries (Gao et al., 2005). Camellia is cross-pollinated plant and inter- and/or intra- species (or cultivars) hybrids naturally and/or artificially, frequently. Therefore, thousands of cultivars

*Corresponding author. E-mail: wxf8080@126.com.

Abbreeviations: RAPD, Random amplified polymorphic DNA; PCR, polymerase chain reaction; dNTP, deoxynucleoside triphosphates; UPGMA, unweighed pair group method with arithmetic average. have developed. It is estimated that about 15,000 camellia cultivars have been identified (Gao et al., 2005). Meanwhile, new cultivars and wild resources are still discovered frequently. This would bring much difficulty on identification, classification, molecular breeding and protection of wild resources. Therefore, it is very urgent and necessary to investigate camellia resources and explore their genetic relationships.

RAPD technology was firstly set up by Welsh and McClelland (1990) and Williams et al. (1990) at almost the same time. It could amplify genome DNA and investigate genetic diversities among samples with a set of random primers. Compared with other molecular markers, RAPD marker features sensitiveness, convenience and rapidness in detection, therefore, it was widely used in many fields such as analysis of genetic relationship (diversity), cultivars identification and gene localization in genome (Lima et al., 2007; Lin et al., 2009; Thiago et al., 2009; Ebrahimi et al., 2009). However, so far, we still know little genetic information on Camellia (or cultivars) because of limited reports by RAPD technology or by other molecular marker (Wachira et al., 1997; Kaundun et al., 2000, Kaundun and Young-Goo, 2002; 
Table 1. Code, Name and features of Camellia cultivars used in the study.

\begin{tabular}{|l|l|l|l|l|l|}
\hline Code & \multicolumn{1}{|c|}{ Name } & \multicolumn{1}{|c|}{ COF $^{1}$} & \multicolumn{1}{|c|}{ DOF $^{2}$ (cm) } & \multicolumn{1}{|c|}{ BP $^{3}$} & OD $^{4}$ \\
\hline N1 & Dujuancha (ND ${ }^{5}$ ) & red & Middle & All the year & 1.85 \\
N2 & Aomai (C. nitidissima) & Golden yellow & Small & Dec.-Feb. & 1.45 \\
N3 & Jinsiyudie (C. japonica) & Bright white & Middle & Jan.-Mar & 1.43 \\
N4 & Lianruicha (C. Theopsis) & white & Small & Mar. & 1.45 \\
N5 & Liujiaobai (C. japonica) & pure white & Middle & Feb.-Apr. & 1.81 \\
N6 & Yumeiren (C. reticulata) & pure white & Large & Jan.-Mar & 1.34 \\
N7 & Zuiyangfei (C. japonica) & bright red & Large & Feb-Mar. & 1.43 \\
N8 & Fengxian (C. japonica) & pink & Small to middle & Mar.- Apr. & 1.35 \\
N9 & Jiuzhonghua (C. japonica) & pink & Small & Feb-Mar. & 1.33 \\
N10 & Hai'ermian (C. japonica) & pink & Large & Jan.-Mar. & 1.59 \\
N11 & Moguangjing (from Japan, ND) & Dark red & Middle & Jan.-Mar. & 1.38 \\
N12 & Hongluzhen (C. japonica) & red & Large & Jan-Mar. & 1.45 \\
N13 & Qiumudan (C. japonica) & salmon pink & Sep.-Dec. & 1.41 \\
N14 & Fair Jury (from New Zealand, ND) & White dotted with violet red & Large & Jan-Mar. & 1.39 \\
N15 & Star above star (from America, C. sasanqua) & White with pale purple & Large & Sep.-Dec & 1.32 \\
\hline
\end{tabular}

Camellia names from Shao and Gao (2003). COF ${ }^{1}$ : color of flower; DOF ${ }^{2}$ : diameter of flower, that is, small $(5-6 \mathrm{~cm})$, middle $(7-11 \mathrm{~cm})$, large $(12$ $-14 \mathrm{~cm}$ ); $\mathrm{BP}^{3}$ : blooming period; $\mathrm{OD}^{4}$ : A260/A280; ND ${ }^{5}$ : not detected.

Tang et al., 2006; Xiao et al., 2008; Kunjupiliai et al., 2009).

RAPD-PCR reaction system features tiny volume $(25$ $\mu \mathrm{L}$, generally), many ingredients (dNTP, polymerase, primers, template, etc) and many steps (pre-denaturing, denaturing, annealing, extension) and many cycles (30 40). So little change of any parameters could affect products drastically (Diakou and Dovas, 2001; Fraga et al., 2002), which indicates its kinetics profile very complex. Therefore, the RAPD-PCR reaction system must be optimized before its application on any kind of materials. The present study performed optimization of RAPD-PCR system by orthogonal experiments and investigated genetic relationships on 15 representative camellia cultivars. The study would do good to further investigation of camellia genome diversity, culti- vars identification, classification and protection, mole- cular breeding, etc.

\section{MATERIALS AND METHODS}

\section{Plant materials and their Genomic DNA extraction}

All camellia cultivars were collected from Zhejiang Hongxin Garden Company (Wenzhou,China). Of them, one common cultivar (Huzhuabai ( $C$. japonica)) was randomly selected for optimization of RAPD-PCR reaction system and other 15 representative cultivars (Table 1) were analyzed with optimized reaction system. Genomic DNA was isolated from camellia tender leaf tissue (in March) with hexa-adecyl-tri-methyl ammonium bromide method (Doyle and Doyle, 1987). The purity and quantity of genomic DNA were detected by spectrophotometry (Thermo electron corp Biomate 5).

\section{Establishment and optimization of RAPD-PCR reaction system}

Optimization of reaction system: Twenty-seven reaction systems were performed by the orthogonal experiment designed by $L_{27}\left(3^{6}\right)$ (Table 2). Temple DNA and primer used in 27 reactions were from sample (Huzhuabai) and primer S7 (GGTGACGCAG) selected randomly. All reaction volumes were $25 \mu \mathrm{L}$ including $2.5 \mu \mathrm{L}$ $10 \times$ Buffer (without $\mathrm{Mg}^{2+}$ ) and sufficient quantum deioned $\mathrm{H}_{2} \mathrm{O}$, respectively. PCR reaction was carried out in a thermal cycler (Tpersonal, Whatman Biometra), programmed for 1 cycle of $3 \mathrm{~min}$ at $94^{\circ} \mathrm{C}$ for predenaturation, followed by 40 cycles of $94^{\circ} \mathrm{C}$ for $30 \mathrm{~s}$ (denaturing), different temperature for $60 \mathrm{~s}$ (annealing) and $72^{\circ} \mathrm{C}$ for $90 \mathrm{~s}$ (extension). Additional extension $\left(72^{\circ} \mathrm{C}\right.$ for $\left.10 \mathrm{~min}\right)$ was used to ensure the completeness of PCR products. Amplification products were stored at $4^{\circ} \mathrm{C}$ for detection.

\section{Analysis of 15 camellia cultivars by RAPD-PCR amplification}

With fifteen $10 \mathrm{nt}$ random primers (Table 3) (Shanghai Bioengineering Company, China), PCR amplification reactions were carried out with the above optimized system, respectively. All PCR products were separated by $1.2 \%$ agarose gel electrophoresis in $0.5 \times \mathrm{TBE}$ buffer, then stained by ethidium bromide (EB) and visualized, photographed under UV light (Gel Doc-It Imaging system (UVP, Bio Doc Co., USA)). Figure 1 represented electrophoresis map from RAPD-PCR amplification reaction products by partial primers.

\section{Data processing and cluster analysis}

All gel bands were scored and the similarity (S) were analyzed and 
Table 2. Orthogonal design $L_{27}\left(3^{6}\right)$ for RAPD-PCR analysis.

\begin{tabular}{|c|c|c|c|c|c|c|}
\hline \multirow{2}{*}{$\begin{array}{l}\text { Treatment } \\
\text { sequence }\end{array}$} & \multicolumn{6}{|c|}{ Factors and levels } \\
\hline & $\begin{array}{c}\mathrm{MgCl}_{2}(25 \mathrm{mM}) \\
(\mu \mathrm{L})\end{array}$ & $\begin{array}{c}\text { dNTP (each } 25 \mathrm{mM}) \\
(\mu \mathrm{L})\end{array}$ & $\begin{array}{c}\text { Primer }(20 \mu \mathrm{M}) \\
(\mu \mathrm{L})\end{array}$ & $\begin{array}{c}\text { Template } \\
\text { (ng) }\end{array}$ & $\operatorname{Tag}(U)$ & $\operatorname{Tm}\left({ }^{\circ} \mathrm{C}\right)$ \\
\hline 1 & $1(1.5)$ & $1(1.0)$ & $1(1.0)$ & $1(40)$ & $1(1.0)$ & $1(34)$ \\
\hline 2 & 1 & 1 & 1 & 1 & $2(1.5)$ & $2(36)$ \\
\hline 3 & 1 & 1 & 1 & 1 & $3(2.0)$ & $3(38)$ \\
\hline 4 & 1 & $2(2.0)$ & $2(2.0)$ & $2(60)$ & 1 & 1 \\
\hline 5 & 1 & 2 & 2 & 2 & 2 & 2 \\
\hline 6 & 1 & 2 & 2 & 2 & 3 & 3 \\
\hline 7 & 1 & $3(3.0)$ & $3(3.0)$ & $3(80)$ & 1 & 1 \\
\hline 8 & 1 & 3 & 3 & 3 & 2 & 2 \\
\hline 9 & 1 & 3 & 3 & 3 & 3 & 3 \\
\hline 10 & $2(2.0)$ & 1 & 2 & 3 & 1 & 2 \\
\hline 11 & 2 & 1 & 2 & 3 & 2 & 3 \\
\hline 12 & 2 & 1 & 2 & 3 & 3 & 1 \\
\hline 13 & 2 & 2 & 3 & 2 & 1 & 2 \\
\hline 14 & 2 & 2 & 3 & 2 & 2 & 3 \\
\hline 15 & 2 & 2 & 3 & 2 & 3 & 1 \\
\hline 16 & 2 & 3 & 1 & 1 & 1 & 2 \\
\hline 17 & 2 & 3 & 1 & 1 & 2 & 3 \\
\hline 18 & 2 & 3 & 1 & 1 & 3 & 1 \\
\hline 19 & $3(2.5)$ & 1 & 3 & 2 & 1 & 3 \\
\hline 20 & 3 & 1 & 3 & 2 & 2 & 2 \\
\hline 21 & 3 & 1 & 3 & 2 & 3 & 1 \\
\hline 22 & 3 & 2 & 1 & 1 & 1 & 3 \\
\hline 23 & 3 & 2 & 1 & 1 & 2 & 2 \\
\hline 24 & 3 & 2 & 1 & 1 & 3 & 1 \\
\hline 25 & 3 & 3 & 2 & 3 & 1 & 3 \\
\hline 26 & 3 & 3 & 2 & 3 & 2 & 2 \\
\hline 27 & 3 & 3 & 2 & 3 & 3 & 1 \\
\hline
\end{tabular}

calculated (Nei and Li, 1979; Rohlf, 2000). A dendrogram was constructed based on similarity matrix unweighed pair group method with arithmetic average cluster analysis (UPGMA) (Sneath and Sokal, 1973).

\section{RESULTS}

\section{Orthogonal analysis on establishment and optimization of RAPD-PCR reaction system}

With orthogonal experiments by $\mathrm{L}_{27}\left(3^{6}\right)$, all amplification products were analyzed by $1.2 \%$ agarose gel electrophoresis. Results showed reaction system 23 (Table 2) could amplify clear, stable and reproducible bands, so we believed that system 23 was a suitable combination for RAPD analysis on camellia cultivars, that is, the optimi- zation system was $10 \times \mathrm{PCR}$ Buffer $(2.5 \mu \mathrm{L}), 25 \mathrm{mM} \mathrm{MgCl}_{2}$ $(2.5 \mu \mathrm{L}), 2.5 \mathrm{mM}$ dNTPs $(2.0 \mu \mathrm{L}), 20 \mu \mathrm{M}$ primer $(1.0 \mu \mathrm{L})$, Tag (1.5 U), temple DNA (40 ng or so) and additional $\mathrm{dd}_{2} \mathrm{O}$ to the total volume $25 \mathrm{uL}$, suitable annealing temperature was $36^{\circ} \mathrm{C}$.

\section{Analysis on genotype polymorphism among the 15 camellia cultivars}

With the optimization system, 15 representative samples were analyzed by 15 primers, respectively, the results showed that the total of clear 102 loci were produced, 79 of which were of polymorphism, indicating the percentage of polymorphic site was $77.54 \%$; The amplification sizes ranged from 0.3 to $4.0 \mathrm{~kb}$ or so. For similarity coefficient 
Table 3. Primers and sequences and each amplification results from 15 samples.

\begin{tabular}{|c|c|c|c|c|}
\hline Primer & Sequence & Total bands & Polymorphic bands & RPB $^{\mathbf{1}}(\%)$ \\
\hline S10 & CTGCTGGGAC & 7 & 7 & $100 \%$ \\
S11 & GATGACCCGT & 10 & 7 & $70.0 \%$ \\
S20 & GGACCCTTAC & 4 & 4 & $100 \%$ \\
S32 & TCGGCGATAG & 8 & 7 & $87.5 \%$ \\
S39 & CAAACGTAGG & 10 & 9 & $90.0 \%$ \\
S43 & GTCGCCGTCA & 8 & 6 & $75.0 \%$ \\
S112 & ACGCGCATGT & 6 & 5 & $83.3 \%$ \\
S128 & GGGATATCGG & 4 & 3 & $75.0 \%$ \\
S216 & GGTGAACGCT & 5 & 4 & $80.0 \%$ \\
S254 & TGGGTCCCTC & 4 & 2 & $50.0 \%$ \\
S256 & CTGCGCTGGA & 7 & 4 & $57.1 \%$ \\
S263 & GTCCGGAGTG & 6 & 4 & $66.7 \%$ \\
S265 & GGCGGATAAG & 7 & 4 & $57.1 \%$ \\
S267 & CTGGACGTCA & 8 & 6 & $75.0 \%$ \\
S300 & AGCCGTGGAA & 8 & 7 & $87.5 \%$ \\
Total & 102 & 79 & $77.54 \%$ & \\
Average & 6.8 & 5.27 & $77.50 \%$ & \\
\hline
\end{tabular}

$\mathrm{RPB}^{1}$ stands for ratio of polymorphic bands (\%).

Table 4. Genetic similarities among 15 samples.

\begin{tabular}{|c|c|c|c|c|c|c|c|c|c|c|c|c|c|c|c|}
\hline & $\mathrm{N} 1$ & N2 & N3 & N4 & N5 & N6 & N7 & N8 & N9 & N10 & N11 & $\mathrm{N} 12$ & $\mathrm{~N} 13$ & N14 & N15 \\
\hline N1 & 1 & & & & & & & & & & & & & & \\
\hline N2 & 0.6326 & 1 & & & & & & & & & & & & & \\
\hline N3 & 0.6112 & 0.6939 & 1 & & & & & & & & & & & & \\
\hline N4 & 0.6735 & 0.6531 & 0.7142 & 10. & & & & & & & & & & & \\
\hline N5 & 0.6289 & 0.6289 & 0.7526 & 0.6907 & 1 & & & & & & & & & & \\
\hline N6 & 0.5816 & 0.6633 & 0.8061 & 0.7245 & 0.7938 & 1 & & & & & & & & & \\
\hline N7 & 0.5714 & 0.6939 & 0.7551 & 0.6735 & 0.7629 & 0.7857 & 1 & & & & & & & & \\
\hline N8 & 0.6428 & 0.6224 & 0.7244 & 0.6836 & 0.8454 & 0.7959 & 0.7653 & 1 & & & & & & & \\
\hline N9 & 0.6486 & 0.6428 & 0.8061 & 0.6837 & 0.7938 & 0.7959 & 0.8265 & 0.8163 & 1 & & & & & & \\
\hline N10 & 0.5979 & 0.7113 & 0.7938 & 0.6598 & 0.7604 & 0.8041 & 0.8144 & 0.7629 & 0.8454 & 1 & & & & & \\
\hline N11 & 0.6122 & 0.6122 & 0.7959 & 0.6939 & 0.7423 & 0.7449 & 0.7350 & 0.7245 & 0.8469 & 0.7732 & 1 & & & & \\
\hline N12 & 0.5918 & 0.6531 & 0.7755 & 0.6734 & 0.7629 & 0.7445 & 0.7959 & 0.7040 & 0.7857 & 0.8454 & 0.7959 & 1 & & & \\
\hline N13 & 0.6082 & 0.6701 & 0.8144 & 0.7526 & 0.8350 & 0.8144 & 0.8247 & 0.8247 & 0.8763 & 0.8229 & 0.7629 & 0.7835 & 1 & & \\
\hline N14 & 0.6489 & 0.6596 & 0.7553 & 0.7340 & 0.7849 & 0.7447 & 0.7766 & 0.7447 & 0.7872 & 0.7849 & 0.8191 & 0.7872 & 0.8387 & 1 & \\
\hline N15 & 0.6383 & 0.6915 & 0.7447 & 0.6596 & 0.7527 & 0.7128 & 0.7872 & 0.7553 & 0.7340 & 0.7527 & 0.7477 & 0.7128 & 0.7849 & 0.8191 & 1 \\
\hline
\end{tabular}

among the 15 samples, they widely ranged from 0.5714 to 0.8763 (Table 4), which represented the closest genetic relation between $N_{9}$ and $N_{13}$ and the furthest between $N_{1}$ and $\mathrm{N}_{7}$, respectively.

\section{Cluster analysis}

The Figure 2 represented the genetic relationships among 15 camellia cultivars. The 15 samples were distinctly 

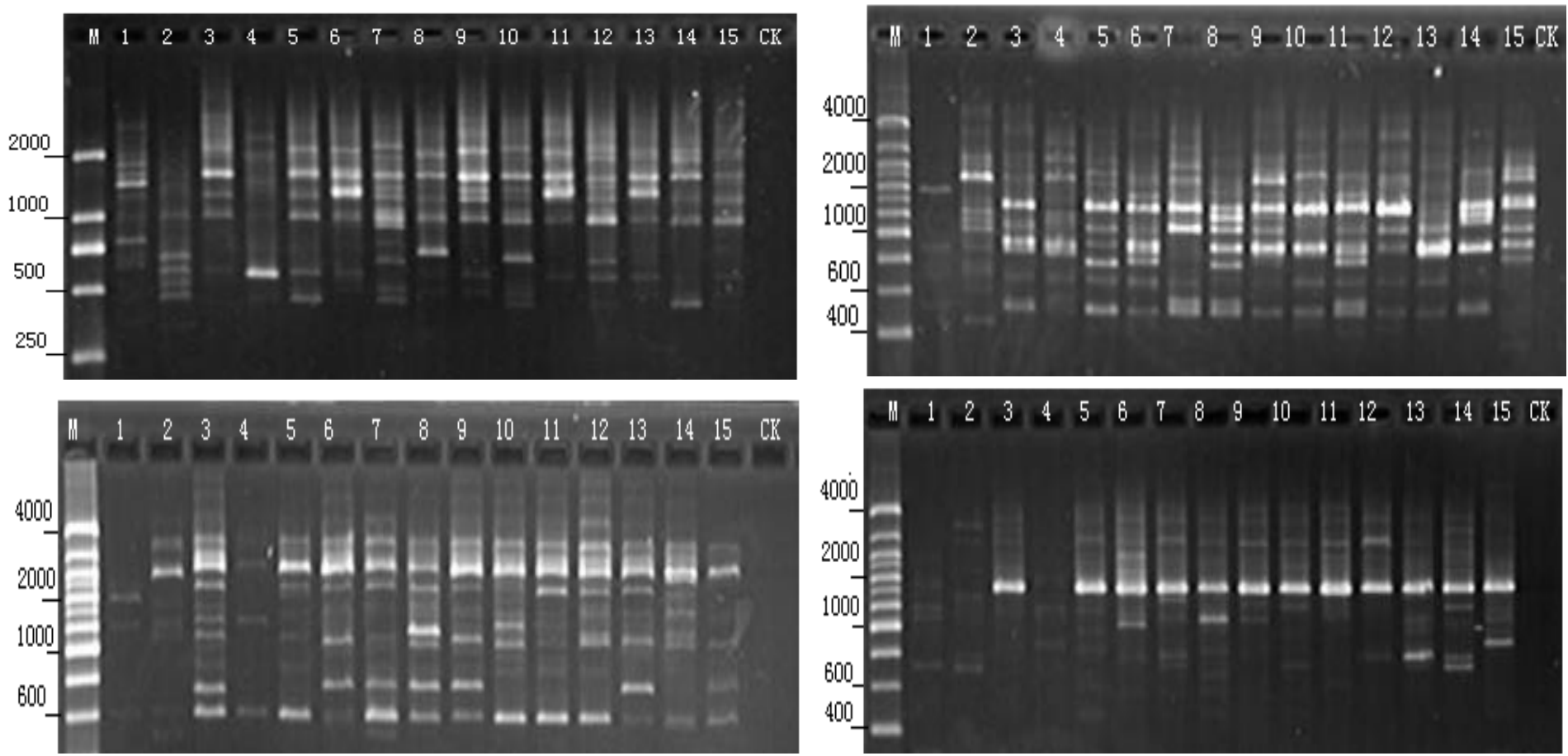

Figure 1. Agarose gel electrophoresis analysis by primer S256 (left-up), S39(left-down) and primerS267(right-up), primerS300(right-down), respectively. M stands for DNA Marker while CK was negative control. Samples from lane1-15 were the same to their serial number (Table 1).

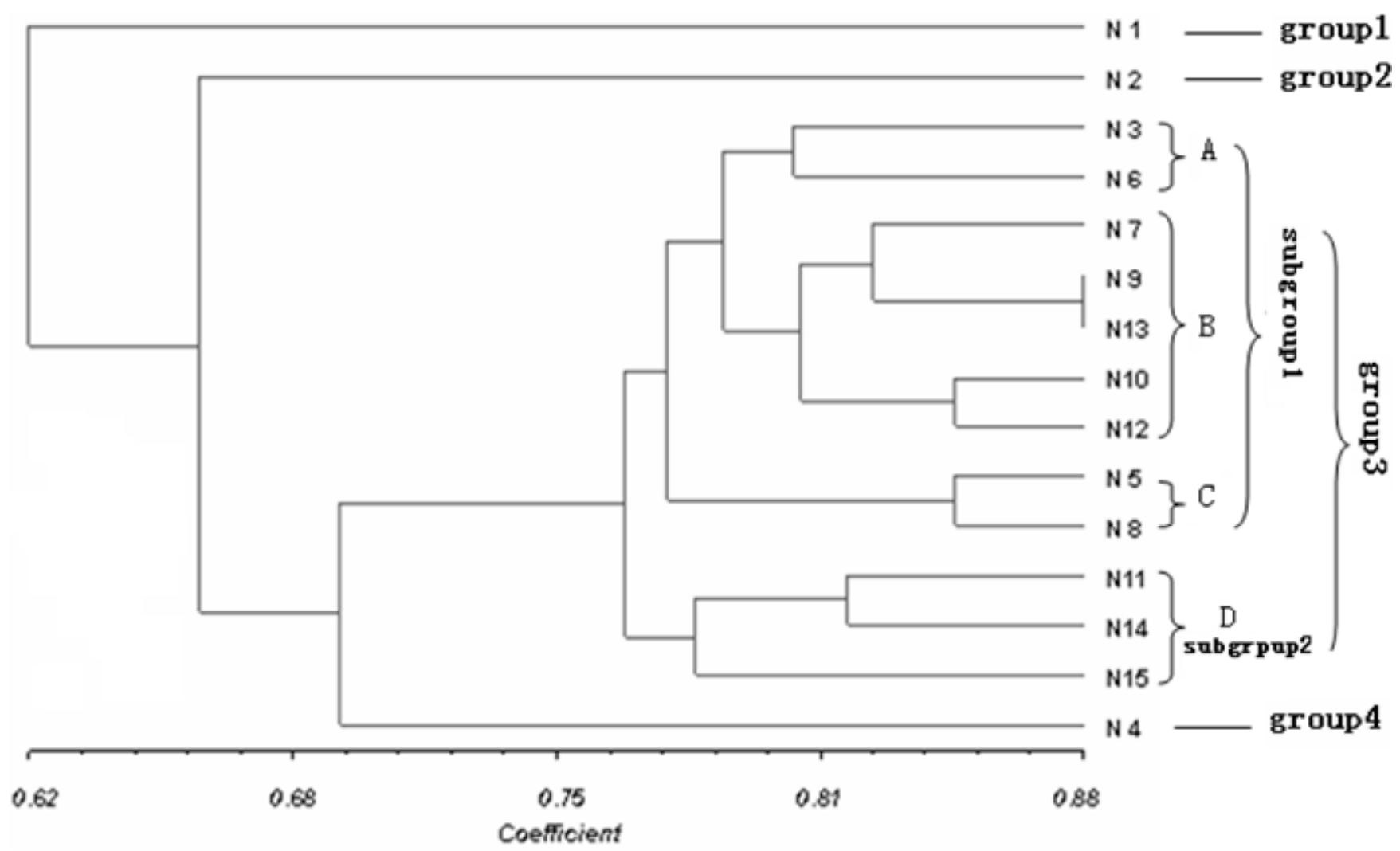

Figure 2. UPGMA dendrogram of 15 samples genotypes based on RAPD-PCR analysis by 15 random RAPD primers. 


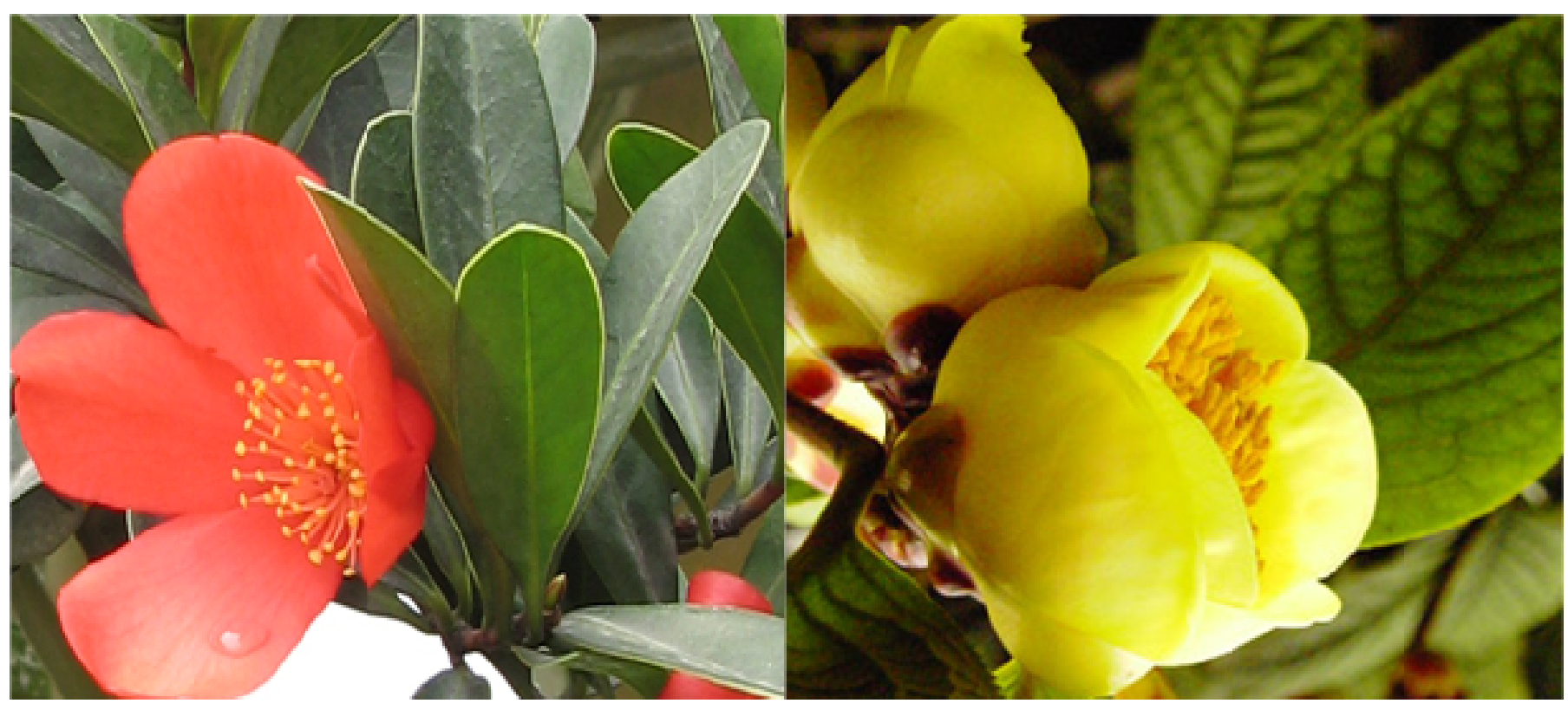

Figure 3. Morphological traits of two unique camellia varieties (left: Dujuancha $\left(\mathrm{N}_{1}\right)$; right: Aomai $\left(\mathrm{N}_{2}\right)$ ).

clustered into four groups at the point 0.75 of similaritycoefficient, that is, $N_{1}$ (group 1); $N_{2}$ (group 2); $N_{3}$ and $\mathrm{N}_{5-15}$ (group 3); $\mathrm{N}_{4}$ (group 4). If we considered group 3 in detail, it could be furthered to divide into two subgroups (Figure 2): Subgroup1 included $\mathrm{A}\left(\mathrm{N}_{3}\right.$ and $\left.\mathrm{N}_{6}\right) /$ $\mathrm{B}\left(\mathrm{N}_{7}, \mathrm{~N}_{9}, \mathrm{~N}_{13}, \mathrm{~N}_{10}, \mathrm{~N}_{12}\right) / \mathrm{C}\left(\mathrm{N}_{5}\right.$ and $\left.\mathrm{N}_{8}\right)$ while subgroup 2 included $\mathrm{D}\left(\mathrm{N}_{11}\right.$ and $\left.\mathrm{N}_{14}, \mathrm{~N}_{15}\right)$.

\section{DISCUSSION}

The volume of RAPD-PCR system was so tiny that change of any ingredient concentrate would affect products drastically. Therefore, it was so difficult even impossible to investigate single ingredient effect (Diakou and Dovas, 2001; Fraga et al., 2002). The present study got suitable RAPD system by orthogonal analysis because of comprehensive consideration of all elements in RAPD analysis. It also indicated that $\mathrm{Mg}^{2+}$ concentrate and annealing temperature could bring big effect (Hernendez et al., 1999). In the study, the genome DNA was isolated from tender leaf tissue and was purified two times by phenol-chloroform after complete treatment of RNase. This resulted in little impurity (such as protein, RNA) in genome DNA and their ratios of A260/A280 ranged from 1.32 to 1.85 (Table 1), indicating available amplification effect. Theoretically, the DNA concentrate should be as low as possible because high concentrate DNA itself may bring false positive bands. The present study acquired ideal effect with 40 ng genome DNA.

The genetic diversities based on RAPD analysis could be reflected by morphological traits. For example, the leaf of sample N1 (Dujuancha (C. japonica)) was thick, cera- ceous and smooth with red petals, moreover, it was a unique camellia species blooming all the year; For sample N2 (Aomai (C. nitidissima)), its petal was unique yellow and small, a kind of exceptional and cherished camellia cultivar (Figure 3); As for sample $\mathrm{N}_{4}$ (Lianruicha (C. Theopsis)), it featured narrow and long leaf, small flower and soft branch; Other 12 samples were of similar morphological traits. In other words, samples $N_{1}, N_{2}, N_{4}$ showed great morphological differences one another compared with other 12 cultivars. Therefore, it was understandable that three samples $\left(\mathrm{N}_{1}, \mathrm{~N}_{2}, \mathrm{~N}_{4}\right)$ clustered into different groups, respectively, while other 12 samples clustered closely (Figure 2). The result also showed that RAPD marker was feasible and suitable to analyze the genetic diversities among camellia cultivars. Meanwhile, it also furthered to represent the RAPD optimization system in this study was suitable.

For group 3, an interesting thing was observed that samples in each subgroup featured similar morphological traits (Table 1). For the petal color of samples in Subgroup $1, N_{3}$ and $N_{6}$ were similar (white); $N_{7}, N_{9}, N_{13}, N_{10}, N_{12}$ were similar (red); while $N_{5}$ (white) and $N_{8}$ (pink) had a little difference. These morphological differences could be clearly represented in the Figure 2, that is, sample $\mathrm{N}_{3}$ and $\mathrm{N}_{6}$ clustered closely (A); sample $\mathrm{N}_{7}, \mathrm{~N}_{9}, \mathrm{~N}_{13}, \mathrm{~N}_{10}, \mathrm{~N}_{12}$ clustered closely (B) while sample $\mathrm{N}_{5}$ and $\mathrm{N}_{8}$ clustered together (C). In other words, after A and B clustered, they furthered to cluster with $C$. This reminded us that the gene(s), controlling petal color, could play critical roles in RAPD analysis. Of course, other genes, which controlled blooming period and flower diameter also played positive roles in RAPD analysis. Actually, the RAPD analysis was very complex, all genes would contribute to positive effect 
though some genes play big roles while others play little roles. Another interesting thing was involved in three samples (N11, N14, N15) in subgroup 2 (D). Though they were introduced to China from different countries (Table 1), they could cluster together closely. One possible explanation was three samples could be hybrid progeny of the same camellia species (or cultivar) and were introduced into different countries, respectively. Therefore, they had relatively high genetic similarities.

\section{ACKNOWLEDGMENTS}

This work was granted by Department of Education of Zhejiang province (Project No.: Y200803397) and Science and Technology Bureau of Wenzhou (Zhejiang, China) (Project No.: N2005A012). The authors were grateful to Hongxin Lin and Xizhi Chen for their kindness in friendly providing the materials.

\section{REFERENCES}

Chattopadhyay P, Besra SE, Gomes A, Das M, Sur P, Mitra S, Vedasiromoni JR (2004). Anti-inflammatory activity of tea (Camellia sinensis) root extract. Life Sci. 74: 1839-1849.

Chen L, Gao QK, Chen DM, Xu CJ (2005). The use of RAPD markers for detecting genetic diversity, relationship and molecular identification of Chinese elite tea genetic resources [Camellia sinensis (L.) O. Kuntze] preserved in a tea germplasm repository. Biodivers. Conserv. 14: 1433-1444.

Diakou A, Dovas Cl (2001). Optimization of random-amplified polymorphic DNA producing amplicons up to $8500 \mathrm{bp}$ and revealing intraspecies polymorphism in Leishmania infantum isolates. Anal. Biochem. 288:195-200.

Doyle JJ, Doyle JL (1987). A rapid DNA isolation procedure for small quantities of fresh leaf tissue. Photochem. Bull. 19: 11-15.

Ebrahimi R, Zamani Z, Kashi A (2009). Genetic diversity evaluation of wild Persian shallot (Allium hirtifolium Boiss.)using morphological and RAPD markers. Sci. Hortic. 119: 345-351

Ferrara L, Montesano D, Senatore A (2001). The distribution of minerals and flavonoids in the tea plant (Camellia sinensis). IL Farmaco. 56: 397-401.

Fraga J, Lázara R, Idalia S, Carlos A, Sarr' I (2002). Optimization of random amplified polymorphic DNA techniques for its use in genetic studies of Trichomonas vaginalis isolates. Infect. Genet. Evol. 2: 73-75.

Gao JY, Clifford RParks Du YQ (2005). Kromogram of major protospecies of Genus Camellia plant. Zhejiang science and technology publishing house. pp. 5-6 (in Chinese and English).

Hernendez P, Martin A, Dorado G (1999). Development of SCARs by direct sequencing of RAPD products: a practical tool for the introgression and marker assisted selection of wheat. Mol. Breed. 5: 245-253.

Kaundun SS, Alexander Z, Young-Goo P (2000). Evaluation of the genetic diversity among elite tea (Camellia sinensis var. sinensis) accessions using RAPD markers. Euphytica. 115: 7-16
Kaundun SS, Young-Goo P (2002). Genetic Structure of Six Korean Tea Populations as Revealed by RAPD-PCR Markers. Crop Sci. 42: 594-601

Khan N, Mukhtar H (2007). Tea polyphenols for health promotion. Life Sci. 81: 519-533.

Kunjupiliai V, Wen-Ju Z, Chih-Hua T (2009). Molecular Taxonomy of Camellia (Theaceae) inferred from nrlTS sequences. Amer. J. Bot. 96(7):1348-1360.

Lima JM, Dass A, Sahu SC, Behera L, Chauhan DK (2007). A RAPD marker identified a susceptible specific locus for gall midge resistance gene in rice cultivar ARC5984. Crop Prot. 26: 1431-1435.

Lin KH, Lai YC, Li HC, Lo SF, Chen LFO, Lo HF (2009).Genetic variation and its relationship to root weight in the sweet potato as revealed by RAPD analysis. Sci. Hortic. 120: 2-7

Nei M, Li WH (1979). Mathematical model for studying genetic variation in terms of restriction endonucleases. Proc. Natl. Acad. Sci. USA. 76: 5269-5273.

Rohlf FJ (2000). NTSYS-pc: Numerical Taxonomy and Multivariate Analysis System, version 2.1. Exeter Software, Setauket, New York.

Shao T, Gao JY (2003). Introduction of 1001 camellia cultivars. The translated articles from the international camellia journal. pp. 56-88 (in Chinese)

Sneath PH, Sokal RR (1973). Numerical Taxonomy: The Principles and Practice of Numerical Classification. Vol. 12. Freeman WH, San Francisco, pp. 102-108

Tadahiro N, Tojiro T, Etsuji H,Nobuyasu E, Shunichi M Chikao N (1985).Camellidins, Antifungal Saponins Isolated from Camellia japonica. Agric. Biol. Chern.49 (4):1181-1186

Tang SQ, Bin XY, Wang Li, Zhong Y (2006). Genetic Diversity and Population Structure of Yellow Camellia (Camellia nitidissima) in China as Revealed by RAPD and AFLP Markers. Biochem. Genet. 44(13): 444-456.

Thiago LDM, Monique IS, Aline SF, Carlos AC (2009). Genetic divergence among gerbera accessions evaluated by RAPD. Sci. Hortic. 121: 92-96.

Wachira FN, Powell W, Waugh R (1997). An assessment of genetic diversity among Camellia sinensis L. (cultivated tea) and its wild relatives based on randomly amplified polymorphic DNA and organelle-specific STS. Heredity, 78: 603-611.

Wachira FN, Waugh R, Hackett CA, Powell W (1995). Detection of genetic diversity in tea (Camellia sinensis) using RAPD markers. Genome, 38: 201-210.

Welsh J, McClelland M (1990). Fingerprinting genomes using PCR with arbitrary primers. Nucleic Acids Res.18: 7213-7218.

Williams JGK, Kubelik AR, Livak KJ, Rafalski JA, Tingey SV (1990). DNA polymorphisms amplified by arbitrary primers are useful as genetic markers. Nucleic Acids Res. 18: 6531-6535.

Xiao W, Hong-Lin C, Yun-Sheng J, Wan-Hui Y, Xue-Jun G, Feng L (2008). Population genetic structure of Camellia nitidissima (Theaceae) and conservation implications. Botanical Studies. 49:147-153.

Young-Goo P, Kaundun SS, Alexander Z (2002). Use of the bulked genomic DNA-based RAPD methodology to assess the genetic diversity among abandoned Korean tea plantations. Gen. Res. Crop Evol. 00: 1-7 